\title{
O.I. Шрамко
}

\section{ФЕНОМЕН КУЛЬТУРИ У СОЦАЛЬНОМУ ПРОСТОРІ СТАНОВЛЕННЯ НАЦІІ}

В контексті сьогодення усвідомлення тієї ролі, яку відіграє культура (і відігравала впродовж усієї історії людства) у процесі націотворення, постає найактуальнішою проблемою сучасного гуманітарного пізнання. Як проблему гуманітарної аури нації влучно окреслила іiі Ліна Костенко в лекції, прочитаній в Національному університеті "Києво-Могилянська академія" 1 вересня 1999 року. "... Кожна нація, - підкреслила знана поетеса і науковець, - повинна мати свою гуманітарну ауру. Тобто потужно емануючий комплекс наук, що охоплюють всі сфери суспільного життя, включно $з$ освітою, літературою, мистецтвом, - в їхній інтегральній причетності до світової культури i, звичайно ж, у своєму неповторно національному варіанті" [6. - C.7].

Етимологія слова "аура" налічує до десятка значень і всі вони пов'язані або з повівом вітерця, або $з$ подихом, або з уявленнями про золото - золоту середину (наприклад, "aurea mediocritas" у Горація ), золотий дощ (епітет Персея "auri gena" - "золотонароджений", адже Юпітер навідав Данаю у вигляді золотого дощу). Асоціативне коло цих значень окреслює той духовнокультурний німб, що золотим сяйвом "огортає" життя цілої нації, оберігаючи це життя та наділяючи його вищим смислом.

Невипадково згадує Костенко і про невловимий на перший погляд зв'язок між поняттями аури та поняттям камікадзе, яке буквально означає вітер богів, божественний вітер, порив якого здатний кинути людину на відчайдушний крок безоглядної самопожертви. Сьогодні таке порівняння здатне шокувати своєю прогностичністю - у вересні 1999-го світ ще не знав ні "Манхеттена", ні чеченського "Норд-Осту". Мова йшла про спробу припустити існування аури цілої нації, а не лише певного біополя окремої особистості, про той божественний вітер, "що кидав покоління за поколінням на боротьбу саме за цей народ, за цей шматок землі, який Бог на планеті подарував саме українцям" [6. - C.10]. 
Що ж створює ауру нації, ауру, яка не лише спонукає людину повсякчас відчувати свою національну причетність і відстоювати свою національну гідність, а й презентує образ нації в світі? Відповідаючи на це питання, Ліна Костенко цілком доречно наголошує на культурних засадах такої презентації. Історія світової культури повсякчас доводить, що образ нації визначається насамперед іiї культурним обличчям. Ауру іспанської нації створили Сервантес, Гойя, Ель Греко, Сарасате, Гарсіа Лорка, про них ми згадуємо, коли чуємо слово "іспанці", а не про морок інквізиції або диктатуру Франко. Нацією філософів і композиторів називають німецьку націю, а національна аура росіян визначається зовсім не вічними смутами і тоталітаризмом, Росія "має свій імідж, тому що у неї були прекрасні вчені й мислителі, письменники й композитори" [6. - С.11]. I прикладів таких безліч.

Отже, природно виникає питання про ауру української нації, про ії світовий імідж. А імідж цей невтішний - у сучасному світі "Україну мало хто знає, iї все ще плутають із Росією, ï проблеми для світу неактуальні, за нею тягнеться шлейф історичних упереджень, не спростованих нами й досі". Більш того, "негативні імпульси щодо української культури пустили глибоке й розгалужене по світу коріння" [6. - С.14]. Проте найстрашніше, що ці негативні імпульси пустили своє коріння і на рідному терені i сьогодні "адаптований розум" пересічного українця вже не потребує ні одвічних культурних висот (найчастіше він навіть не має уявлень про ці висоти), ні духовного камертону національних культурних цінностей.

Змиритися $з$ цією атрофією органічної потреби у культурі означає назавжди втратити своє національне, власне обличчя, свою історію і не тільки свій світовий імідж, а й своє ім'я. "Розбуджена окраденою", Україна як ніколи потерпає сьогодні від незахищеності отим культурним ореолом, гуманітарною аурою, яка набувається віками і говорить по присутність нації у світі.

"Велике диво, - наголошує Л.Костенко, - що ця нація на сьогодні ще $\epsilon$, вона давно вже могла б знівелюватися й зникнути. Фактично це раритетна нація, самотня на власній землі у своєму великому соціумі, а ще самотніша в універсумі людства. 
Фантом Свропи, що лише під кінець століття почав набувати для світу реальних рис. Вона чекає своїх філософів, істориків, соціологів, генетиків, письменників, митців" [6. - С.30]. Тобто, вона чекає свого "упредметнення" культурою. Ніякі "заклинання культури економікою" ніколи не призведуть до духовного відродження нації. Бути може тільки навпаки. Нація створюється культурою і стверджується культурою.

Тому процеси націотворення, особистісного й державного самоствердження, виховання національної самосвідомості та національної гідності можливі лише за умови "якомога послідовнішого, теоретично вимогливого, критичного ставлення до культури, до власного культурного само розуміння". А "будь-які спроби обминути фундаментальність культурницької проблематики, задовольнитися побіжними, поспіхом виробленими поглядами є заздалегідь приреченими на забуття" [2. - С.466].

Тож не дивно, що проблема культури та іiі ролі в житті нації усе більше хвилює суспільну й громадську думку, змушує замислюватися найвидатніших представників вітчизняної літератури й мистецтва. На цій тематичній ниві все гучніше й переконливіше звучить і голос філософів, а філософське осмислення культури в Україні дедалі набуває вагомішого статусу.

Проте теоретичні підвалини такого осмислення потребують грунтовного опрацювання, адже фундаментальні й найпоширеніші поняття сучасного соціокультурного дискурсу - культура, нація, духовність - й досі залишаються поняттями "без берегів", куди кожен бажаючий відповідно до власних уподобань ладен вкласти будь-який зміст (В.Горський).

Найпершим таким поняттям $є$ поняття культури. На сьогоднішній день важко віднайти інше поняття, котре мало б стільки різних відтінків смислу. У повсякденному житті ми зустрічаємося 3 цією багатовідтінковістю на кожному кроці. В газетах $\mathrm{i}$ журналах, по радіо і телебаченню, у вуличному натовпі, у промовах громадських та державних діячів раз у раз лунають нарікання на занепад культури, заклики до ії відродження та піднесення, вимоги створити умови для розвитку культури тощо. При цьому поняття "культура" вживається або для позначення сфери функціонування соціокультурних інститутів (ідеологія, мораль, 
релігія, мистецтво тощо), або асоціюється з чемністю та освіченістю ("культура поведінки", "культура мислення", "культура почуттів" тощо), або обмежується сферою мистецтва та релігії, коли мова йде про "науку і культуру", "культуру і економіку", "новини культурного життя" тощо.

Як бачимо, в широкому вжитку культура слугує оцінним поняттям і найчастіше відноситься до таких рис особистості, які вірніше було б назвати не культурою, а культурністю, освіченістю, вихованістю. В цілому ж, повсякденною свідомістю культура сприймається як сукупність духовних цінностей. Проте і в науковому вжитку, як одне 3 фундаментальних понять соціально-гуманітарного пізнання, поняття культури при всій складності та різноманітті підходів до його розуміння найчастіше позначає комплекс духовного життя людини та суспільства.

Цей сучасний європейський концепт культури як утворення духовного має тривалу етимологічну, історико-культурну, етноісторичну та історико-філософську традицію, причому традицію дискусійну й суперечливу. I сьогодні ще дослідники не мають єдиної думки 3 приводу того, як і коли конституюється "європейське поняття про культуру". Чи можна вести відлік від введеного Цицероном філософсько-риторичного тропу "cultura animi"? Чи можуть вважатися (і якщо можуть, то якою мірою) аналогами європейського поняття про культуру латинське "humanitas2 і грецьке "paideia"? I чи не вірогідніше відштовхуватись все ж таки від ренесансних передумов формування європейської концептосфери культури, які найближчим шляхом виводять на розвідки Дж.Віко та німецьких просвітників?

Осмислення культури як символу буття людського духу має в дослідженні смислового поля "культура - нація" принципове значення. Ясність у цьому питанні (бодай, хоча б наближення до такої ясності) дозволить окреслити зміст поняття культури і не повертатися більше (вірніше сказати, не кидатися) до проблем поділення культури на матеріальну та духовну, розрізнення цивілізації та культури і загалом до проблеми багатозначності й хаотичності уявлень про культуру.

Що стосується останньої, то вона принципово не може бути вирішеною. I це пояснюється не лише складністю і багатогран- 
ністю самого явища культури, але й відмінністю світоглядних та методологічних позицій мислителів та вчених, що досліджують феномен культури, а також задачами тих дисциплін, в межах яких вони проводять свої дослідження (деякі дослідники вважають, що кількість визначень поняття культури наближається сьогодні до тисячної відмітки).

Принциповість питання концептосфери культури для вирішення проблеми "культура - нація" виявляється також і в тому, що тільки осмислення культури як сфери буття людського духу дозволяє вести мову про культуру як чинник націотворення, адже сучасне розуміння нації не як природної, а духовної засади грунтується на майже двохсотлітній філософській традиції "ототожнення нації з усією іiї духовною культурою в цілому, як ідеальною іпостассю цієї нації" [4. - С.30].

Ця думка вже до початку ХХ століття всамоочевиднюється настільки, що, як підкреслює О.Забужко, дає змогу В.Липинському відмовитися "від спроб здефінювати культуру описово, через її складові, щоб натомість запропонувати визначення сутності культури через іiі етнозахисну функцію - функцію слугувати засобом виживання свого суб'єкта: "...сума певних суспільних вартостей - що в боротьбі за існування себе оправдали та в досвіді поколінь показали себе для самозбереження тієї групи (що їх витворила. - О.3.) найкращими - творить те, що ми називаємо культурою" [4. - С.30-31].

Необхідно підкреслити, що й сучасний націоналізм як одна 3 потужних європейських традицій політичної думки, розвиваючи власне розуміння нації, повсякчас наголошує на ії духовнокультурній сутності. Насторожено ставлячись "до індустріальної цивілізації з ії тенденцією до уніфікації життєвого середовища...", "цивілізації націоналізм протиставляє культуру, духовний підтекст суспільного життя" [7. - С.18].

Осмислення культури як духу нації уможливлює і усвідомлення національної ідеї як ідеї культури. Такий ракурс філософської рефлексії національної ідеї, що давно вже стала в Україні традиційною, але не застарілою, дозволяє виявити сутнісні засади філософеми "національна ідея". А це необхідно зробити, бо й саме поняття національної ідеї належить до тих, суть яких зі 
зростанням частоти вживання "не лише не прояснюється, а навпаки, все більше затьмарюється" [3. - С.77]. Тому це поняття також вимагає свого категоріального обгрунтування з урахуванням як історичної традиції, так і сучасних тенденцій соціального буття і особливо тенденції "переключення" національної енергії 3 "політики" на "культуру", про яке свого часу говорив Є.Маланюк і яке веде до буттєвісного виміру національного саморозуміння.

Отже, якщо погодитися 3 тим, що процес становлення нації, який спирається на ствердження національної ідеї (а історія повсякчас нагадує нам, що саме "ідеї правлять світом" (Кондорсе), "вимірюється" насамперед рівнем культурного національного й особистісного самовизначення - шляхом послідовного усвідомлення природи й сутності культури, то найперше, з чого треба почати, так це з виявлення творчого потенціалу культури, 3 дослідження ії креативно-діяльнісної природи, яка й робить культуру не лише об'єктом, не лише контекстом, а й суб'єктом національного руху. Це - проблема субстанційних засад культури, яка постає сьогодні однією з найактуальніших проблем наукового дискурсу.

Актуальність цієї проблеми підкреслюється тим незаперечним фактом, що який би підхід до визначення культури ми не обрали - антропологічний чи ціннісний, адаптивний чи соціологічний, історичний чи функціональний тощо, жоден 3 них не здатний спростувати креативно-діяльнісної природи культури. Діяльність і творчість - ось ті граничні, фундаментальні засади, на яких будується сучасне уявлення про культуру і які спроможні перетворити ï не лише на дієвий чинник творення нації, а й надати їй значно ширші повноваження - повноваження інституту націотворення.

Розгляд культури як інституту націотворення на перший погляд може видатися перебільшенням, але тільки на перший. Якщо ж звернутися до історії, то вже у Віко ідея культури безпосередньо пов'язується із встановленням націй. "Культура (humanitas) розуміється Віко не тільки як освіта та просвітництво, але як начало, що формує національний світ у його цілісності та єдності. Для Віко світ культури - світ націй-народів. Ледве не вперше 
в європейській історії (у всякому разі, значно раніше романтиків, що звернулися до цієї теми), Віко пов'язує докупи поняття "культури" і феномен "національного" [1. - С.28].

3 часів Віко ця думка не лише неодноразово виникала (в різних контекстах) на терені філософському та суспільногромадському, а й мала цілком реальні приклади свого практичного втілення. Сучасне повернення до цієї ідеї, а воно вже досить чітко окреслюється як у теоретичних наукових напрацюваннях, так і в суспільно-політичній думці, вимагає свого узагальнення і грунтовного осмислення, адже практична вартість тут може бути надто високою.

Проте скільки б ми не говорили про роль культури у процесі національного становлення, завжди постає питання: а що саме стоїть за отим узагальненим словом "культура"? Тобто, необхідно виявити ті структурні елементи, які несуть на собі, а вірніше, здатні нести основне творче навантаження у процесі національної розбудови.

Видається доцільним у цьому питанні взяти за основу класифікацію елементів духовної культури Р.Ейслера, який виділяє культуру інтелектуальну (наука, філософія, просвіта), естетичну (мистецтво і література), етичну, соціальну (мова, побут, традиції та звичаї, право і політика), релігійну. При цьому зробимо деякі зміни: додамо сюди ще культуру художню і саме до неї віднесемо мистецтво та літературу.

Таким чином, маємо шість конкретних креативнодіяльнісних культурних сил: інтелектуальну (наукову, філософську, просвітницько-освітянську), релігійну, етичну, естетичну, художню, соціальну. Звісно, будь-яке поділення культури на структурні елементи завжди є умовним, неповним і нечітким. Можна багато сперечатися, але запропоноване поділення, на нашу думку, досить виразно окреслює те уявлення про культуру, яке склалося в межах сучасного соціокультурного дискурсу. Крім того, воно все ж таки вносить у дослідження системну ясність і допомагає рухатись у напрямку певних конкретних результатів.

Спробуємо тепер розібратися у сучасному стані вітчизняної культури, стані буття духу України, який не лише спрямовує 
розвиток процесу національного становлення, а $€$ його онтологічним та феноменологічним підгрунтям. Стан цей не просто невтішний, що констатують усі дослідники, стан цей відзначається якоюсь надзвичайною хаотичністю, невизначеністю та неузгодженістю, що аж ніяк не сприяє повноцінному розвиткові процесу націотворення.

Проте вже зараз у цьому хаосі можна віднайти ті паростки культурного майбуття, які здатні перетворитися на могутні атрактори становлення нації. Звісно, найбільше нас хвилює питання можливості впливу на їхнє формування. Перспективи такої можливості презентує синергетична концепція соціокультурної динаміки, що на сьогодні користується досить широкою популярністю. Вона видається доволі вдалою і для пояснення процесу як зародження, так і розвитку тих креативних сил, що спрямовують "ренесанс" української нації. Як на мене, то вочевидь і іiї перспектива для осмислення сучасної постмодерністської ситуації, яка дедалі усе ширше охоплює і нашу країну.

Постмодерн пропонує стратегію діалогу з хаосом і це дуже важливо - зрозуміти, що ні подолати, ні гармонізувати хаос неможливо, треба навчитися з ним жити, поважати його, розуміти i намагатися віднайти себе у цьому хаосі. I тут думка йде далі: якщо культура як надскладна система дійсно розвивається за синергетичним принципом і сама віднаходить шляхи свого розвитку, то сучасна ситуація постмодерну є результатом таким же "природним" і невідворотним, як і будь-яка ситуація, що складається у системах природних. Якщо сьогодні постмодерн видається утворенням хаотичним і руйнівним, то не виключено, що завтра цей хаос перетвориться на усталене ціле. Адже хаос містить у собі як руйнівне начало, так і конструктивне, творче. На думку прихильників синергетичного підходу, "сам хаос може бути захистом від хаосу, механізмом виведення на структуриатрактори еволюції" [5. - С.98]. Намагатися перебороти те, що сьогодні видається хаосом, не просто безперспективно, це майже завжди небезпечно, бо може призвести (і багато разів призводило) до катастрофічних наслідків. Інша справа, - виходячи 3 фактичної ситуації, дослідженої якомога докладніше, спробувати віднайти можливість впливати на подальший шлях розвитку 
культури, спрямовувати цей розвиток відповідно до наших уявлень про майбутнє.

Тому якщо ми не вдоволені хаотичністю сучасного процесу націотворення і якщо ми хочемо змінити ситуацію на краще, то нам прийдеться зазирнути у культурну "плазму" цього процесу i визначити той спектр шляхів еволюції своїх власних тенденцій, тенденцій розвитку власної культури, який і окреслить майбуття нації, а 3 нею і майбуття окремої особистості як суб'єкта нації. Чим чіткішим буде бачення цих шляхів, тим впевненішими будуть наші дії і тим реальнішу ми матимемо надію на позитивний результат.

\section{ЛІТЕРАТУРА}

1. Асоян Ю., Малафеев А. Открытие идеи культуры (Опыт русской культурологии середины XIX - начала XX веков). - М.: ОГИ, 2000.

2. Бистрицький $C$. Післямова // Феномен української культури: методологічні засади осмислення. - К.: "Фенікс", 1996.

3. Горський В. Ще раз про українську ідею // Філософськоантропологічні читання' 98. - К.: Стилос, 1999.

4. Забужкко $O$. Філософія української ідеї та європейський контекст: франківський період. - К.: Основи, 1993.

5. Князева E.H. Приключения научного разума: синергетическое видение научного прогресса // Когнитивная эволюция и творчество. М.: Институт философии РАН, 1995.

6. Костенко Л. Гуманітарна аура нації або дефект головного дзеркала. - К.: Видавничий дім "КM Academia", 1999.

7. Лановий $B$., Проценко $O$. Націоналізм, нація та національна держава // Націоналізм: Антологія. - К.: Смолоскип, 2000. 